\title{
Prospects in folate receptor-targeted radionuclide therapy
}

\author{
Cristina Müller ${ }^{1}$ and Roger Schibli ${ }^{1,2}$ \\ ' Center for Radiopharmaceutical Sciences ETH-PSI-USZ, Paul Scherrer Institute, Villigen-PSI, Switzerland \\ ${ }^{2}$ Department of Chemistry and Applied Biosciences, ETH Zurich, Zurich, Switzerland
}

\section{Edited by:}

Jean-Pierre Pouget, Institut National

de la Santé et de la Recherche

Médicale, France

Reviewed by:

Hsin-Ell Wang, National Yang-Ming

University, Taiwan

Gerrit Jansen, VU University Medical

Center, Netherlands

*Correspondence:

Cristina Müller, Center for

Radiopharmaceutical Sciences

ETH-PSI-USZ, Paul Scherrer Institute,

5232 Villigen, Switzerland

e-mail: cristina.mueller@psi.ch
Targeted radionuclide therapy is based on systemic application of particle-emitting radiopharmaceuticals which are directed toward a specific tumor-associated target. Accumulation of the radiopharmaceutical in targeted cancer cells results in high doses of absorbed radiation energy whereas toxicity to non-targeted healthy tissue is limited. This strategy has found widespread application in the palliative treatment of neuroendocrine tumors using somatostatin-based radiopeptides. The folate receptor (FR) has been identified as a target associated with a variety of frequent tumor types (e.g., ovarian, lung, brain, renal, and colorectal cancer). In healthy organs and tissue FR-expression is restricted to only a few sites such as for instance the kidneys. This demonstrates why FR-targeting is an attractive strategy for the development of new therapy concepts. Due to its high FR-binding affinity $\left(K_{\mathrm{D}}<10^{-9} \mathrm{M}\right)$ the vitamin folic acid has emerged as an almost ideal targeting agent. Therefore, a variety of folic acid radioconjugates for nuclear imaging have been developed. However, in spite of the large number of cancer patients who could benefit of a folate-based radionuclide therapy, a therapeutic concept with folate radioconjugates has not yet been envisaged for clinical application. The reason is the generally high accumulation of folate radioconjugates in the kidneys where emission of particle-radiation may result in damage to the renal tissue. Therefore, the design of more sophisticated folate radioconjugates providing improved tissue distribution profiles are needed. This review article summarizes recent developments with regard to a therapeutic application of folate radioconjugates. A new construct of a folate radioconjugate and an application protocol which makes use of a pharmacological interaction allowed the first preclinical therapy experiments with radiofolates. These results raise hope for future application of such new concepts also in the clinic.

Keywords: folate receptor, folic acid, radionuclide therapy, cancer

\section{FOLATE RECEPTOR AND FOLIC ACID}

Folate receptors (FRs) are glycoproteins with molecular weights of $38-44 \mathrm{kDa}$ which exist in several isoforms $(1,2)$. The FR- $\alpha$ and the FR- $\beta$ are both anchored in the cell membrane by a glycosylphosphatidyl-inositol domain. The FR- $\alpha$ is expressed at a few sites of normal epithelial membranes for instance in the proximal tubule cells of the kidneys (3-5) and in a variety of solid cancer types of epithelial origin (6). Cancer types with the highest frequency of FR- $\alpha$ expression are ovarian (90\%), endometrial (90\%), brain (90\%), lung (78\%), and renal carcinomas (75\%) (6-9). On the other hand, FR-expression in cancer of the head and neck $(52 \%)$, breast $(48 \%)$, stomach $(38 \%)$, and colon-rectum $(32 \%)$ was found at intermediate frequencies $(6,9)$. It is important to recognize that the expression level of the FR- $\alpha$ on tumors may have a prognostic value as it has been found to correlate with the survival rate of the patients. In ovarian, endometrial and breast carcinomas as well as in primary and metastatic colorectal cancer overexpression of the FR- $\alpha$ correlated with a worse survival (10-13). In contrast, evaluation of a large number of non-small cell lung cancers revealed that high FR-expression levels correlated with a better survival (14).

The FR- $\beta$ is found in the placenta and in normal hematopoietic tissue (e.g., spleen, thymus, and monocytes) $(15,16)$ but also in hematopoietic malignancies such as acute and chronic myelogenous leukemia (17) and on activated macrophages (16). Targeting of the FR- $\beta$ expressed on activated macrophages has initially been associated primarily with targeting of inflammatory diseases such as rheumatoid arthritis $(9,18,19)$. However, the FR- $\beta$ may have future implications also in the field of oncology as a marker of tumor-associated macrophages (20, 21).

The vitamin folic acid binds with high affinity to the FR $\left(K_{\mathrm{D}}=10^{-9} \mathrm{M}\right)$ and hence, it can be used as a targeting ligand. Compared to other (e.g., peptide- or protein-based) targeting agents the use of folic acid provides several advantages (22). Folic acid is small in size (441 Da) and accessible for chemical modification. Moreover it is relatively stable in solution of a wide range of $\mathrm{pH}$-values and at elevated temperatures (22). Due to its function as a vitamin, folic acid is not toxic to healthy organs and tissue nor does it provoke immune reactions. Since binding to the FR results in an endocytotic uptake of folic acid cellular delivery of even larger payloads which are conjugated to folic acid is accessible $(23,24)$. All of these features together make folic acid an excellent candidate for tumor targeting allowing selective delivery of attached probes to FR-expressing (cancer) cells. 


\section{FR-TARGETED THERAPIES}

In the first instance it is the FR- $\alpha$ which attracted most interest as a tumor-associated target for imaging purposes and targeted therapy concepts $(9,25)$. Targeting of FR-positive tumor cells in vitro and in vivo has been exemplified by a number of research groups using folic acid conjugates with a variety of therapeutic probes $(25,26)$. For FR-targeted therapies several concepts have been developed based on e.g., highly toxic chemotherapeutics, drug-loaded liposomes, nanoparticles, and oligonucleotides which were attached to folic acid [reviewed in (27)]. Among those the most advanced approach is clearly the concept of using folic acid-targeted chemotherapeutics, most importantly EC145, a folate conjugate of a vinca alkaloid, desacetylvinblastine monohydrazide (28). Already in 2009 a phase I clinical study was published reporting on the clinical pharmacokinetics and exposure-toxicity relationship of EC145 in cancer patients (29). Meanwhile, several clinical studies performed with EC145 (Vintafolide ${ }^{\mathrm{TM}}$ ) demonstrated the benefit of this therapy for patients with cancer of the lung and ovaries (30-33)

For FR-targeted immunotherapy as another targeted therapy concept folic acid is exploited to carry an attached hapten to the surface of tumor cells (34). The aim of this approach is to render the tumor cells more immunogenic upon FR-binding of the folatehapten conjugates. The pre-existing or induced immunity of the patient allows the haptens to attract anti-hapten-antibodies and to provoke immune reactions. Hence, it enhances the anticancer immune reaction of the host against hapten-decorated tumor cell (34). Several preclinical studies proved the potential of this concept for cancer therapy (35-37). Another strategy of FR-targeted immunotherapy is the use of FR-binding antibodies $(38,39)$. Several concepts of (radio)immunotherapy with FR-binding chimeric (e.g., MOv18) and humanized (e.g., MORAb-003) monoclonal antibodies were developed and evaluated in (pre)clinical studies $(38,40-44)$.

Various different drugs, including chemotherapeutics (e.g., doxorubicin and paclitaxel) have been selectively delivered to FRexpressing cancer cells through use of folic acid conjugated carriers such as liposomes and nanoparticles $(26,45,46)$. Possible advantages of this strategy are an increased drug loading capacity and the fact that the larger size of these targeting constructs prevents renal filtration and hence, undesired retention in the kidneys (27). From in vivo investigations with FR-targeted carriers labeled with radionuclides $\left({ }^{99 \mathrm{~m}} \mathrm{Tc},{ }^{188} \mathrm{Re},{ }^{68} \mathrm{Ga},{ }^{64} \mathrm{Cu}\right)(47-50)$ it is apparent that nanoparticles and liposomes usually accumulate in the reticuloendothelial system (RES) while the in vivo targeting effect remains poor $(47,48)$.

\section{GENERAL FEATURES OF FOLATE RADIOPHARMACEUTICALS}

In the last two decades our group and others have focused on the development of folate-based radiopharmaceuticals (51). The aim was to design new tools for nuclear imaging of FRpositive cancer via single photon emission computed tomography (SPECT) and positron emission tomography (PET) (5254). More recently, several endeavors were undertaken in view of a therapeutic application of folate radioconjugates using particle-emitting radioisotopes (55-57).
A general feature of folate-based radiopharmaceuticals is their specific accumulation in FR-positive tumor (xeno)grafts. However, accumulation of radioactivity is also always seen in FRpositive organs and tissue such as the kidneys, the salivary glands, and the choroid plexus (58). The distribution profile of radiofolates varied according to their chemical structure with one of the most important feature being a highly hydrophilic character (54). In all of the cases undesired accumulation of radiofolates was found in the renal cortex where the FR is expressed in the proximal tubule cells of the brush border membrane $(3,5$, 58). These circumstances resulted in commonly low tumor-tokidney ratios $(<0.2)$ of radiofolates. This situation is undesired in view of a therapeutic application because of the inherent risk of damage to the radiosensitive kidneys by a high dose burden from particle-radiation (56).

\section{STRATEGIES TO IMPROVE THE TISSUE DISTRIBUTION OF RADIOFOLATES}

A high radioactivity dose burden to the kidneys and as a consequence the risk of damage to the radiosensitive renal tissue particularly in patients with hypertension, diabetes, or other risk factors is an issue in the course of targeted radionuclide therapy $(59,60)$. Administration of high dosed amino acids, usually lysine and arginine, is a means applied in the clinics to reduce unspecific accumulation of radiopeptides (e.g., somatostatin analogs) in the kidneys (61). However, this strategy is not applicable for folate radioconjugates since other than in the case of radiopeptides, renal accumulation is specific due to binding of radiofolates to FRs (56). Application of diuretics or acidification of the urine did also not have a positive impact on renal retention of radiofolates (56). Therefore, alternative strategies are required. In the first approach antifolates were applied in combination with radiofolates with the aim to improve the tissue distribution profile of radioactivity $(62,63)$. In a second approach the folate conjugate's backbone was modified with an albumin-binding entity in order to enhance the circulation time in the blood and therewith possibly increase the tumor-to-kidney ratio (64).

\section{APPLICATION PROTOCOL OF RADIOFOLATES COMBINED WITH PEMETREXED}

The effects of three clinically used antifolates [methotrexate, raltitrexed, and pemetrexed (65), Figure 1] were investigated in combination with a ${ }^{99 \mathrm{~m}} \mathrm{Tc}(\mathrm{CO})_{3}$-labeled folate conjugate with the aim to increase the tumor uptake of the radiofolate (62). This study design was based on the observation that incubation of cancer cells with antifolates resulted in an increased uptake of radiofolates in vitro $(62,66)$.

The in vivo data showed that the accumulation of the radiofolate in KB tumor xenografts remained unaffected but a significantly reduced uptake of radioactivity was found in the kidneys. This resulted in clearly improved tumor-to-kidney ratios, with the best results obtained with pemetrexed (Figure 2) $(62,67)$.

The same effect was successfully reproduced in different tumor mouse models (KB, IGROV-1, and SKOV-3 tumors in nude mice and M109 tumors in Balb/c mice) and variable folate radioconjugates $\left[{ }^{99 \mathrm{~m}} \mathrm{Tc}(\mathrm{CO})_{3}\right.$-folate, ${ }^{99 \mathrm{~m}} \mathrm{Tc}$-EC20, 
<smiles>Nc1nc2ncc(CNc3ccc(C(=O)NC(CCC(=O)O)C(=O)O)cc3)nc2c(=O)[nH]1</smiles><smiles>CN(Cc1cnc2nc(N)nc(N)c2n1)c1ccc(C(=O)NC(CCC(=O)O)C(=O)O)cc1</smiles><smiles>Cc1nc2ccc(CN(C)c3ccc(C(=O)NC(CCC(=O)O)C(=O)O)s3)cc2c(=O)[nH]1</smiles><smiles>Nc1nc2[nH]cc(CCc3ccc(C(=O)NC(CCC(=O)O)C(=O)O)cc3)c2c(=O)[nH]1</smiles>

FIGURE 1 | Folic acid and antifolates. Chemical structures of (A) folic acid and the antifolates (B) methotrexate, (C) raltitrexed (Tomudex ${ }^{\mathrm{TM}}$ ), and (D) pemetrexed (Alimta TM ).

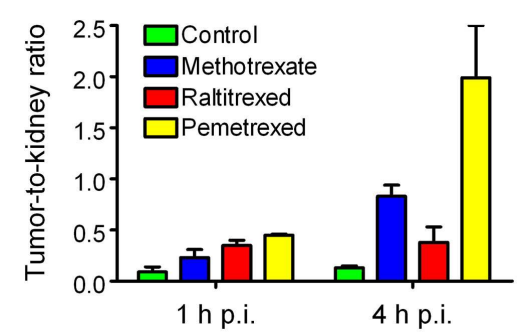

FIGURE 2 | Effects of antifolates on the tumor-to-kidney ratios of radiofolates. Tumor-to-kidney ratios obtained at 1 and $4 \mathrm{~h}$ after injection of

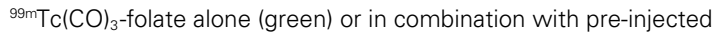
methotrexate (blue), raltitrexed (red), or pemetrexed (yellow).

${ }^{111}$ In-DTPA-folate, ${ }^{111} \mathrm{In} /{ }^{177} \mathrm{Lu}$-DOTA-click-folate, ${ }^{67} \mathrm{Ga}$-DOTABz-folate ( $\left.{ }^{67} \mathrm{Ga}-\mathrm{EC} 0800\right),{ }^{68} \mathrm{Ga}$-NODAGA-folate] $(55,62,63$, $67-$ 69). The injection protocol and the related SPECT/CT images using ${ }^{177} \mathrm{Lu}-\mathrm{EC} 0800$ are shown in Figure 3. The underlying mechanism of this effect is not yet clear but a topic of current investigations in our laboratories. The combination of folate radioconjugates and pemetrexed is, however, appealing in view of a therapeutic application. In this respect, we hypothesized that pemetrexed would have a dual role if it was combined with folate-based radionuclide therapy. On one hand it would reduce undesired renal uptake of radiofolates and on the other hand it may have an effect as a chemotherapeutic $(70,71)$ or radiosensitizing agent $(72-74)$ on the tumor tissue and thus enhance the therapeutic efficacy on the tumors.

\section{DESIGN OF A FOLATE CONJUGATE WITH AN ALBUMIN-BINDING ENTITY}

Increasing the serum half-life of pharmaceuticals by serum protein binding may be a measure to improve the pharmacokinetic properties of otherwise rapidly cleared molecules (75). Based on the results which are reported in the literature with antibody fragments that exhibited a non-covalent association with serum proteins $(76,77)$, it was hypothesized that albumin-binding properties would improve the tissue distribution of radiofolates as well. Therefore, a DOTA-folate conjugate was developed with an integrated small-molecular weight albumin-binding entity which was previously identified from a DNA-encoded chemical library based on the lead structure 4-( $p$-iodophenyl)butyric acid (78). This novel DOTA-folate conjugate ( $\mathrm{cm} 09$, Figure $4 \mathbf{B}$ ) was fully evaluated in its ${ }^{177} \mathrm{Lu}$-labeled version and compared with the data obtained with a conventional ${ }^{177}$ Lu-labeled DOTA-folate conjugate ( ${ }^{177} \mathrm{Lu}-\mathrm{EC} 0800$, Figure 4A) (64).

The in vitro cell uptake properties of ${ }^{177} \mathrm{Lu}-\mathrm{cm} 09$ were comparable to those of other folate radioconjugates (64). Different was however, its feature of binding to plasma proteins as demonstrated by an in vitro assay (64). In vivo biodistribution studies were performed with ${ }^{177} \mathrm{Lu}-\mathrm{cm} 09$ and ${ }^{177} \mathrm{Lu}-\mathrm{EC} 0800$ in athymic nude mice bearing KB tumor xenografts (Figure 5). The enhanced blood circulation time of ${ }^{177} \mathrm{Lu}-\mathrm{cm} 09$ compared with ${ }^{177} \mathrm{Lu}-\mathrm{EC} 0800$ resulted in a tumor accumulation of ${ }^{177} \mathrm{Lu}-\mathrm{cm} 09$ which was $\sim 2.5$ fold higher ( $\sim 18 \% \mathrm{ID} / \mathrm{g}, 4 \mathrm{~h}$ p.i. $)$ than the uptake of ${ }^{177} \mathrm{Lu}-\mathrm{EC} 0800$ ( $\sim 7.5 \% \mathrm{ID} / \mathrm{g}, 4 \mathrm{~h}$ p.i.) (64). On the other hand, renal retention of ${ }^{177} \mathrm{Lu}-\mathrm{cm} 09$ was relatively low ( $28 \% \mathrm{ID} / \mathrm{g}, 4 \mathrm{~h}$ p.i.) compared to other folate conjugates that lack an albumin-binding entity such as ${ }^{177} \mathrm{Lu}-\mathrm{EC} 0800$ (>70\% ID/g, $4 \mathrm{~h}$ p.i.) (64). These findings resulted in a sevenfold improved tumor-to-kidney ratio $(\sim 0.7,4 \mathrm{~h}$ p.i. $)$ for ${ }^{177} \mathrm{Lu}-\mathrm{cm} 09$ compared to the ratio obtained with ${ }^{177} \mathrm{Lu}-\mathrm{EC} 0800$ ( $\sim 0.1,4 \mathrm{~h}$ p.i.). The excellent in vivo properties of ${ }^{177} \mathrm{Lu}-\mathrm{cm} 09$ opened new perspectives for the development of folate-based radionuclide therapy.

To further improve the tumor-to-kidney ratio of the longcirculating ${ }^{177} \mathrm{Lu}-\mathrm{cm} 09$, biodistribution studies were performed with ${ }^{177} \mathrm{Lu}$-cm09 and pemetrexed using KB tumor-bearing mice. Pemetrexed was administered according to the same application protocol as it was previously employed with conventional folate radioconjugates $(55,63,67)$. Independent on whether or not pemetrexed was pre-injected, the tumor uptake was about $\sim 18 \%$ ID/g $4 \mathrm{~h}$ after injection. In contrast, reduced renal accumulation $(16.81 \pm 2.25 \% \mathrm{ID} / \mathrm{g})$ of radioactivity was found $4 \mathrm{~h}$ after injection of ${ }^{177} \mathrm{Lu}$-cm09 if it was combined with pemetrexed compared to the amount of accumulated ${ }^{177} \mathrm{Lu}-\mathrm{cm} 09$ if it was applied as a single agent $(28.05 \pm 1.35 \% \mathrm{ID} / \mathrm{g}, 4 \mathrm{~h}$ p.i.) (64). Thus, pre-injected pemetrexed increased the tumor-to-kidney ratio $(1.07 \pm 0.25,4 \mathrm{~h}$ p.i) compared to control values at the same time after injection of ${ }^{177} \mathrm{Lu}-\mathrm{cm} 09(0.65 \pm 0.07,4 \mathrm{~h}$ p.i.). However, at later time points after injection of ${ }^{177} \mathrm{Lu}-\mathrm{cm} 09$ the kidney reducing effect of pemetrexed was not observed anymore (64). Most probably, these 

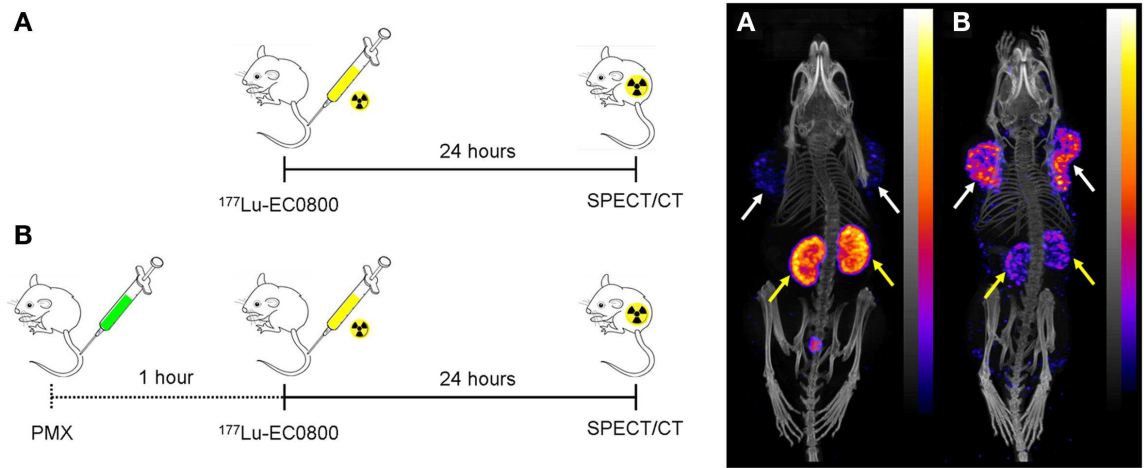

FIGURE 3 | Effect of pemetrexed on the tissue distribution of radiofolates. Injection scheme (left) and whole-body SPECT/CT

images of KB tumor-bearing mice $24 \mathrm{~h}$ after injection of

${ }^{177}$ Lu-EC0800 (right). (A) Injection of only ${ }^{177}$ Lu-EC0800 (20 MBq) and corresponding SPECT/CT image. (B) Injection of ${ }^{177} \mathrm{Lu}-\mathrm{EC} 0800$ (20 MBq, Figure 4A) and PMX $(0.4 \mathrm{mg})$ and corresponding SPECT/CT images. Tumors and kidneys are indicated with white and yellow arrows.<smiles></smiles>

B<smiles></smiles>

FIGURE 4 | DOTA-folate conjugates. Chemical structures of (A) EC0800 $(56,64)$ and (B) cm09 (64).

findings were a result of the fact that pemetrexed was more quickly cleared from the blood circulation than ${ }^{177} \mathrm{Lu}-\mathrm{cm} 09$. Therefore, the pemetrexed related effect to reduce the kidney uptake of ${ }^{177} \mathrm{Lu}$ $\mathrm{cm} 09$ was not maintained for the fraction of ${ }^{177} \mathrm{Lu}-\mathrm{cm} 09$ which was still in the blood circulation when pemetrexed was already excreted (64).

\section{FOLATE RECEPTOR TARGETED RADIONUCLIDE THERAPY - FIRST RESULTS}

Both of the aforementioned approaches, a pharmacological intervention with pemetrexed and a chemical modification of the folate conjugate with an albumin-binding entity resulted in improved tissue distribution profiles of radioactivity. Employing either of these approaches for radionuclide therapy in a preclinical setting was the subject of recent research activities in our laboratories. The decay properties of the therapeutic radionuclides which were employed for these studies are listed in Table 1.

IN VIVO COMBINATION THERAPY OF PEMETREXED AND ${ }^{177}$ LU-EC0800 In a recent study the combined application of ${ }^{177} \mathrm{Lu}-\mathrm{EC} 0800$ (Figure 3A) and pemetrexed (Figure 1D) was investigated using $\mathrm{KB}$ tumor-bearing nude mice (79). Four groups of six athymic 


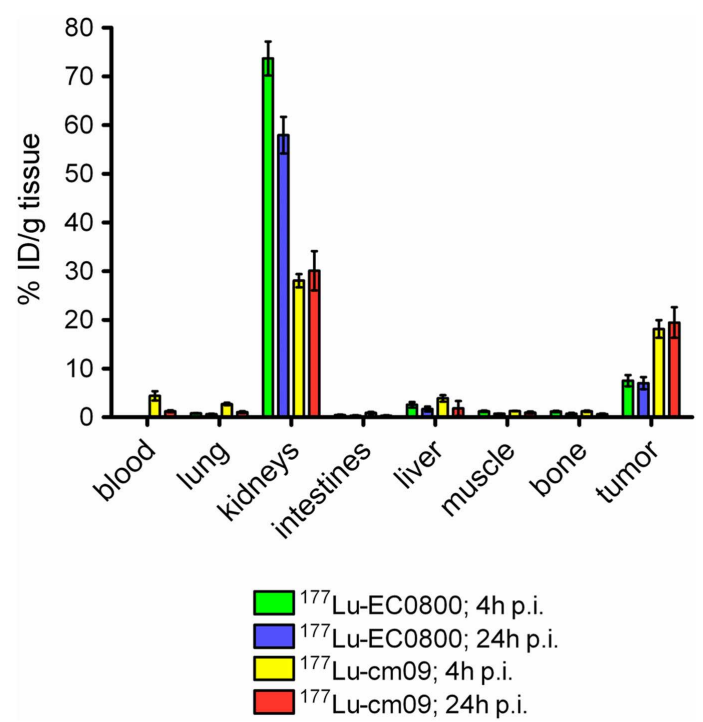

FIGURE 5 | Comparison of the tissue distribution of ${ }^{177} \mathrm{Lu}$-EC0800 and ${ }^{177} \mathrm{Lu}-\mathbf{c m} 09$. Biodistribution data 4 and $24 \mathrm{~h}$ after injection of ${ }^{177} \mathrm{Lu}-\mathrm{EC} 0800$ and ${ }^{177} \mathrm{Lu}-\mathrm{cm} 09$ in athymic nude mice, bearing KB tumor xenografts.

Table 1 | Therapeutic radioisotopes used for folate-based radionuclide therapy.

\begin{tabular}{llll}
\hline Isotope & ${ }^{177} \mathbf{L u}$ & ${ }^{161} \mathbf{T b}$ & ${ }^{149} \mathbf{T b}$ \\
\hline Half-life & $159.4 \mathrm{~h}$ & $165.4 \mathrm{~h}$ & $4.12 \mathrm{~h}$ \\
$\mathrm{E} \alpha$ & - & - & $3.967 \mathrm{MeV}(16.7 \%)$ \\
$\mathrm{E} \beta_{(\text {av) }}^{-}$ & $0.134 \mathrm{MeV}(100 \%)$ & $0.154 \mathrm{MeV}(100 \%)$ & $0.730 \mathrm{MeV}$ \\
$\mathrm{E} \gamma$ (intensity) & $112.9 \mathrm{keV} \mathrm{(6.17 \% )}$ & $25.7 \mathrm{keV}(23.2 \%)$ & $165.0 \mathrm{keV}(26 \%)$ \\
& $208.4 \mathrm{keV}(10.4 \%)$ & $48.9 \mathrm{keV}(17.0 \%)$ & $352.2 \mathrm{keV}(29 \%)$ \\
& & $74.6 \mathrm{keV}(10.2 \%)$ & $388.6 \mathrm{keV}(18 \%)$ \\
& & & $652.1 \mathrm{keV}(16 \%)$
\end{tabular}

nude mice with $\mathrm{KB}$ tumor xenografts received only saline (group A), pemetrexed at a high dose $\left(2 \times 0.8 \mathrm{mg}\right.$, group B), ${ }^{177} \mathrm{Lu}-\mathrm{EC} 0800$ $(1 \times 20 \mathrm{MBq})$, and pemetrexed at a low dose $(1 \times 0.4 \mathrm{mg})$ to reduce renal uptake (group C) or ${ }^{177} \mathrm{Lu}-\mathrm{EC} 0800(1 \times 20 \mathrm{MBq})$ and a high dose of pemetrexed $(2 \times 0.8 \mathrm{mg}$, group $\mathrm{D})$. Application of even a high dose of pemetrexed alone had almost no effect on tumor growth in mice of group B, compared with control animals of group A (Figure 6A). However, the application of ${ }^{177} \mathrm{Lu}-\mathrm{EC} 0800$ resulted in a tumor growth delay (group C) which was increased if it was combined with a high dose of pemetrexed (group D) (Figure 6A). The therapeutic effect of ${ }^{177} \mathrm{Lu}-\mathrm{EC} 0800$ was also reflected by the increased average survival time of mice (group C: 30 days) compared to control mice (group A: 20 days) and mice which received only pemetrexed (group B: 24.5 days) (Figure 6B) (79). However, the clearly most favorable therapy protocol was the combination of ${ }^{177} \mathrm{Lu}$-EC0800 with a high dose of pemetrexed (group D) which resulted in an average survival time of 35 days (Figure 6B) (79).
These findings indicated a radiosensitizing effect of pemetrexed as it was previously reported in other in vitro and in vivo studies that combined pemetrexed with external radiation therapy (72, $73,80,81)$. An additional study was conducted with non-tumorbearing mice over a time period of several months to investigate the potential impairment of the kidneys. It was demonstrated that pemetrexed was able to protect kidneys from radio-nephrotoxicity (79). Further and more detailed studies will be warranted to investigate the utility of this combination in view of a potential clinical application.

\section{FOLATE RECEPTOR TARGETED RADIONUCLIDE TUMOR THERAPY USING} ${ }^{177}$ LU-CM09

The first published therapy experiment with a folate radioconjugate was performed with $\mathrm{KB}$ tumor-bearing nude mice using ${ }^{177} \mathrm{Lu}-\mathrm{cm} 09$ (64). Groups of five mice each were treated with only saline (group A) or with the unlabeled DOTA-folate $\mathrm{cm} 09$ (group B). One group received ${ }^{177} \mathrm{Lu}-\mathrm{cm} 09$ in a single injection of $20 \mathrm{MBq}$ (group $\mathrm{C}$ ), another group received two injections of $10 \mathrm{MBq}$ each (group D) and the last group received three injections of $7 \mathrm{MBq}$ each (group E) (Figure 7A). The individual body weight and tumor volume was measured every other day. The results showed a constant tumor growth in mice of groups A and $\mathrm{B}$ which did not receive radioactivity (Figure $7 \mathrm{~B}$ ). In all mice of groups $\mathrm{C}$ to $\mathrm{E}$ tumor growth was clearly delayed with the best effect achieved in mice of group $\mathrm{C}$ which had been injected with the whole amount of $20 \mathrm{MBq}{ }^{177} \mathrm{Lu}-\mathrm{cm} 09$ in one single injection (Figure 7B). The average survival time of control mice of group A and group B was 27 and 24 days, respectively, whereas an almost doubled survival time was observed for mice of groups D and E ( 48 and 46 days, respectively). In mice which received $20 \mathrm{MBq}{ }^{177} \mathrm{Lu}-\mathrm{cm} 09$ in one single injection the tumors disappeared completely in four of five mice and hence these four mice were still alive at the end of the study which prevented the determination of an average survival time (64).

\section{FOLATE RECEPTOR TARGETED $\alpha$ - AND $\beta$-RADIONUCLIDE TUMOR THERAPY USING ${ }^{149 / 161}$ TB-CMO9}

By using the same DOTA-folate conjugate $(\mathrm{cm} 09$, Figure $4 \mathbf{B})$ as previously employed with ${ }^{177} \mathrm{Lu}(64)$ a pilot therapy study was performed with therapeutic terbium radioisotopes (82). ${ }^{161} \mathrm{~Tb}$ decays by the emission of $\beta$-particles and provides similar decay properties to ${ }^{177} \mathrm{Lu}$ (Table 1) $(82,83) .{ }^{149} \mathrm{~Tb}$ decays by emission of short-ranged $\alpha$-particles with a half-life of $4.12 \mathrm{~h}$ (Table 1) (82). Since the availability of ${ }^{149} \mathrm{~Tb}$ was limiting in this study the experiments were performed with only a small number of mice bearing KB tumor xenografts.

In the $\alpha$-therapy study, three mice received only saline (group A) and three mice received twice an injection of 1.1 and $1.3 \mathrm{MBq}$ of ${ }^{149} \mathrm{~Tb}-\mathrm{cm} 09$, respectively (group B). In two of the treated mice the tumor growth was clearly delayed and in one mouse the tumors disappeared completely (Figure 8A). Compared to untreated control mice of group $A$, the average survival time was significantly prolonged $(p<0.05)$ in mice of group $\mathrm{B}$. The $\beta^{-}$-therapy study was carried out with five mice which received only saline (group A) and another five mice which received 


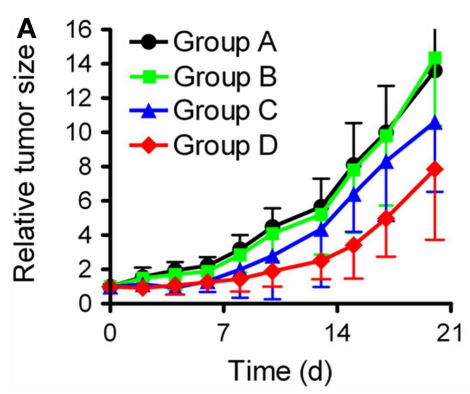

FIGURE 6 | Graphs of tumor growth and survival. Preclinical study with athymic nude mice bearing KB tumor xenografts. (A) Relative tumor size and (B) survival rate of mice of group $A$ (control), group $B$

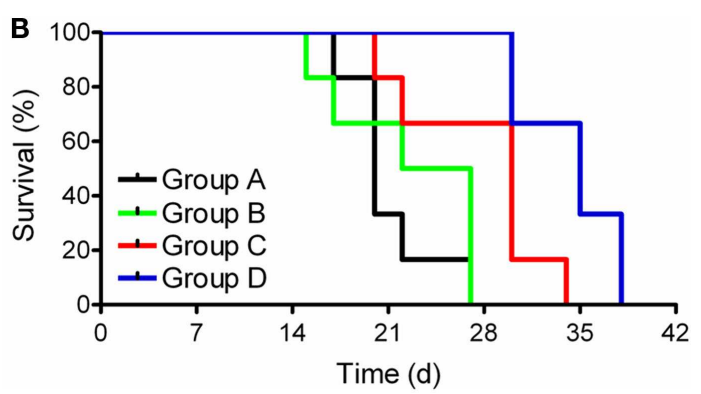

$\left(2 \times 0.8 \mathrm{mg}\right.$ pemetrexed), group C $\left(20 \mathrm{MBq}{ }^{177} \mathrm{Lu}-\mathrm{EC} 0800\right.$ and $0.4 \mathrm{mg}$ pemetrexed), and group D (20 MBq ${ }^{177} \mathrm{Lu}-\mathrm{EC} 0800$ and $2 \times 0.8 \mathrm{mg}$ pemetrexed).

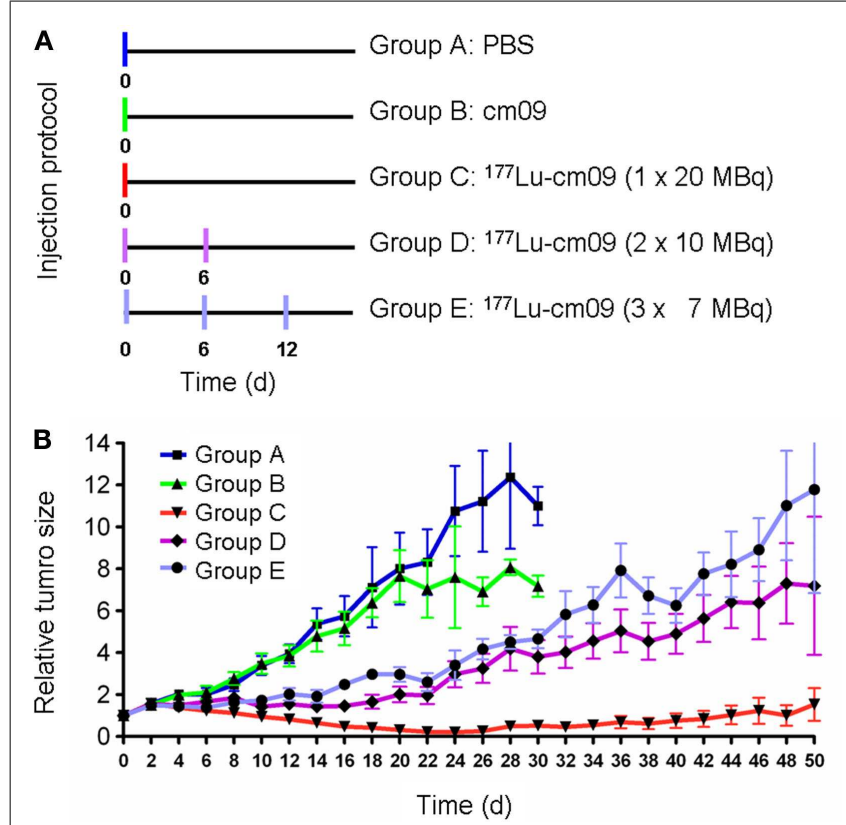

FIGURE 7 | Design and results of the therapy study. (A) Application protocol and (B) average relative tumor size for mice of groups A-E. This research was originally published in Ref. (64). (Cby the Society of Nuclear Medicine and Molecular Imaging, Inc.

$11 \mathrm{MBq}$ of ${ }^{161} \mathrm{~Tb}-\mathrm{cm} 09$ (group B). The overall survival time of control mice was 28 days. In four of the five treated mice of group $\mathrm{B}, \mathrm{KB}$ tumors disappeared completely and hence these mice were still alive at day 56 when the study was terminated (Figure 8B).

The results obtained with ${ }^{177} \mathrm{Lu}-\mathrm{cm} 09$ and ${ }^{149 / 161} \mathrm{~Tb}-\mathrm{cm} 09$ indicated the potential of FR-targeted radionuclide therapy by using folic acid as a targeting ligand. Although the therapy regimes reported in these studies were well tolerated by the test animals, there is a potential risk of damage to the kidneys by particleradiation. Therefore, kidney function was monitored in a preliminary study over 6 months in non-tumor-bearing mice which received ${ }^{177} \mathrm{Lu}-\mathrm{cm} 09$ (20 MBq/mouse) (unpublished data). Blood

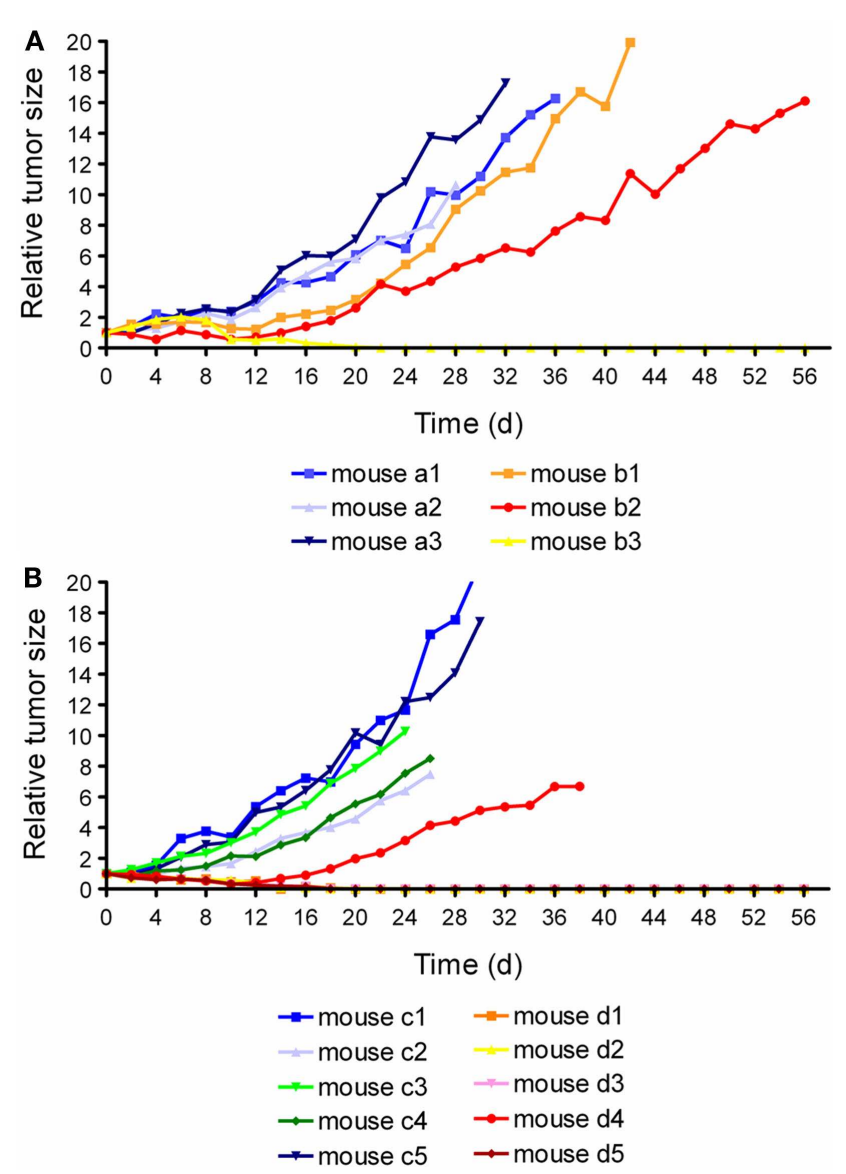

FIGURE 8 | Graphsof tumor growth from each individual mouse.

(A) Relative tumor size of mice of the $\alpha$-radionuclide therapy study (a1-a3: control mice; b1-b3: mice treated with ${ }^{149} \mathrm{~Tb}-\mathrm{cm} 09$ ). (B) Relative tumor size of mice of the $\beta^{-}$- radionuclide therapy study (c1-c5: control mice; d1-d5: ${ }^{161} \mathrm{~Tb}-\mathrm{cm} 09$ treated mice). This research was originally published in Ref. (82). (Oby the Society of Nuclear Medicine and Molecular Imaging, Inc.

plasma parameters were analyzed and quantitative SPECT experiments using ${ }^{99 \mathrm{~m}} \mathrm{Tc}$-DMSA were performed to estimate potential impairment of kidney function as previously reported (84). 
Although signs of radio-nephrotoxicity were not observed, more recent investigations indicate long-term impairment of the kidney function if higher amounts of folate radioconjugates are administered. Hence, further preclinical studies with larger cohorts of mice will be clearly necessary to provide more detailed information about the suitability of this therapy concept.

\section{FOLATE RECEPTOR TARGETED RADIONUCLIDE TUMOR THERAPY USING RADIOACTIVE LIPOSOMES}

In terms of radionuclide therapy the approach of using liposomeor nanoparticle-based carriers for passive or targeted delivery of particle-emitting radionuclides to cancer cells is scarcely reported in the literature but has recently been reviewed by Sofou (85). It could be in particular attractive for radionuclides that are inappropriate for direct complexation by conventional chelation concepts (86). An example that made use of folic acid decorated liposomes as carriers for the $\alpha$-emitting radionuclides radium $\left({ }^{223} \mathrm{Ra}\right)$ and actinium $\left({ }^{225} \mathrm{Ac}\right)$ has been reported by Larsen and Co-workers (87). The radioactive liposome formulations possessed binding properties to FR-expressing cancer cells in vitro and were stable in serum with only low release of radionuclides. Hence, this or similar approaches may have the potential for an in vivo translation in the future.

\section{STABILITY, RADIOLYSIS, TOXICITY, AND SAFETY ASPECTS OF FOLATE-BASED RADIOCONJUGATES}

Folate radioconjugates were found to be very stable in PBS and blood plasma at $37^{\circ} \mathrm{C}$ with only marginal release of radiometals over time (56). ${ }^{177} \mathrm{Lu}-\mathrm{cm} 09$ showed a particularly high in vitro stability with $>99 \%$ intact product over 6 days in human plasma (64). Little is known about potential radiolysis of folate radioconjugates (64). However, since there are studies reporting on the degradation of folate molecules exposed to high temperatures, ultraviolet light, and oxygen (88-90) it is likely that radiolytic processes would occur in highly active formulations of radiofolates. In view of a clinical application of therapeutic folate radioconjugates extensive investigations will be required with respect to the stabilization of radioconjugates by using quenchers such as for instance ethanol and ascorbic acid.

Since folic acid and folates are essential nutritions for the human organism and can be administered by supplements in mg-amounts, folate derivatives are expected to be well tolerated even if they were applied for radiotherapeutic purposes, where the injected amount would not exceed about $200 \mu \mathrm{g}$. Nevertheless, the high uptake of folate radioconjugates in the kidneys is of concern in terms of long-term radionephropathy caused by particleradiation if the folate conjugates were used for radionuclide therapy as mentioned above.

\section{CHALLENGES FOR CLINICAL TRANSLATION AND FUTURE PERSPECTIVES}

For a clinical translation of the "pemetrexed protocol" in combination with therapeutic radiofolates it will be crucial to answer the question on whether pemetrexed would have the same kidney reducing effect of radiofolates in man than it has in mice. Given that this would be the case a further critical point may be the fact that pemetrexed is not yet approved for ovarian, endometrial, and cervical cancer, which are the tumor types with the highest FR-expression level $(6,9)$. At the moment non-small cell lung cancer would clearly be the ideal candidate for this combination because of frequent FR-expression in this cancer type and the FDAapproved indication of pemetrexed for the treatment of non-small cell lung cancer (91-93). However, preclinical results of this combination in a lung tumor mouse model will be required to confirm the applicability of this approach also in other than cervical and ovarian tumors types.

The development of a folate conjugate which was chemically modified with an albumin-binding entity meant a significant step forward in the development of a folate radioconjugates for therapeutic applications (64). Excellent results were achieved with ${ }^{177} \mathrm{Lu}-\mathrm{cm} 09$ and ${ }^{149 / 161} \mathrm{~Tb}-\mathrm{cm} 09$ in terms of tumor growth inhibition and tolerability in mice $(64,82)$. For a safe application of targeted radionuclide therapy the tumor-to-kidney ratio of accumulated radioactivity should be above one. In this respect, it has to be critically acknowledged that the uptake and retention of radiolabeled $\mathrm{cm} 09$ in the kidneys is still high relative to the tumor uptake. This aspect needs to be considered with regard to a potential clinical translation of this approach. Future development must clearly focus on alteration of the tracer design. Such an intervention is expected to result in an improved tissue distribution profile with respect to an increased tumor-to-kidney ratio of radioactivity.

\section{SUMMARY AND CONCLUSION}

Targeted radionuclide therapy showed impressive results for the palliative treatment of cancer such as neuroendocrine tumors. Due to the large number of tumor types which overexpress the FR and the ideal characteristics of folic acid as a targeting ligand the development of therapeutic folate radioconjugates holds great promise for the management of cancer diseases in the future. The drawback of a high renal accumulation of conventional radiofolates can largely be overcome by co-application of the antifolate pemetrexed or by a chemical modification of the folate radioconjugate with an albumin-binding entity. Both strategies resulted in significantly increased tumor-to-kidney ratios and hence, allowed the performance of preclinical therapy studies using particle-emitting isotopes. Application of ${ }^{177} \mathrm{Lu}-\mathrm{EC} 0800$ benefited from the co-administered pemetrexed not only in that it reduced undesired kidney uptake but also by an enhanced anticancer effect which was mediated by pemetrexed's action as a chemotherapeutic agent. Nevertheless, application of a chemically modified folate radioconjugate with optimized tissue distribution characteristics is more likely translatable to a clinical setting than the combination with a chemotherapeutic agent. We believe that a further improvement of the tracer design will finally allow application of FR-targeted radionuclide therapy in patients.

\section{ACKNOWLEDGMENTS}

A large part of the research reported in the article was financially supported by the Swiss National Science Foundation (Ambizione PZ00P3_121772 \& PZ00P3_138834), COST-BM0607 (C08.0026), and the Swiss Cancer League (KLS-02762-02-2011). 


\section{REFERENCES}

1. Antony AC. Folate receptors. Annu Rev Nutr (1996) 16:501-21. doi:10.1146/annurev.nu.16.070196. 002441

2. Elnakat H, Ratnam M. Distribution, functionality and gene regulation of folate receptor isoforms: implications in targeted therapy. Adv Drug Deliv Rev (2004) 56:1067-84. doi: 10.1016/j.addr.2004.01.001

3. Holm J, Hansen SI, Hoiermadsen M, Bostad L. A high-affinity folate binding-protein in proximal tubule cells of human kidney. Kidney Int (1992) 41:50-5. doi:10. 1038/ki.1992.7

4. McMartin KE, Morshed KM, Hazen-Martin DJ, Sens DA. Folate transport and binding by cultured human proximal tubule cells. Am J Physiol (1992) 263:F841-8.

5. Birn H, Spiegelstein O, Christensen EI, Finnell RH. Renal tubular reabsorption of folate mediated by folate binding protein 1. J Am Soc Nephrol (2005) 16:608-15. doi:10. 1681/ASN.2004080711

6. Parker N, Turk MJ, Westrick E, Lewis JD, Low PS, Leamon CP. Folate receptor expression in carcinomas and normal tissues determined by a quantitative radioligand binding assay. Anal Biochem (2005) 338:284-93. doi:10.1016/j.ab.2004. 12.026

7. Weitman SD, Lark RH, Coney LR, Fort DW, Frasca V, Zurawski VR, et al. Distribution of the folate receptor GP38 in normal and malignant cell lines and tissues. Cancer Res (1992) 52:3396-401.

8. Garin-Chesa P, Campbell I, Saigo PE, Lewis JL, Old LJ, Rettig WJ. Trophoblast and ovarian cancer antigen LK26 - sensitivity and specificity in immunopathology and molecular identification as a folatebinding protein. Am J Pathol (1993) 142:557-67.

9. Low PS, Kularatne SA. Folatetargeted therapeutic and imaging agents for cancer. Curr Opin Chem Biol (2009) 13:256-62. doi:10.1016/ j.cbpa.2009.03.022

10. Toffoli G, Russo A, Gallo A, Cernigoi C, Miotti S, Sorio R, et al. Expression of folate binding protein as a prognostic factor for response to platinum-containing chemotherapy and survival in human ovarian cancer. Int $J$ Cancer (1998) 79:121-6. doi:10.1002/ (SICI)1097-0215(19980417)79: 2<121::AID-IJC4>3.0.CO;2-V

11. Hartmann LC, Keeney GL, Lingle WL, Christianson TJ, Varghese B, Hillman D, et al. Folate receptor overexpression is associated with poor outcome in breast cancer. Int J Cancer (2007) 121:938-42. doi:10. 1002/ijc.22811

12. Brown Jones M, Neuper C, Clayton A, Mariani A, Konecny G, Thomas $\mathrm{MB}$, et al. Rationale for folate receptor alpha targeted therapy in "high risk" endometrial carcinomas. Int $J$ Cancer (2008) 123:1699-703. doi: 10.1002/ijc. 23686

13. D'Angelica M, Ammori J, Gonen M, Klimstra DS, Low PS, Murphy L, et al. Folate receptor-alpha expression in resectable hepatic colorectal cancer metastases: patterns and significance. Mod Pathol (2011) 24:1221-8. doi:10.1038/modpathol. 2011.82

14. Iwakiri S, Sonobe M, Nagai S, Hirata T, Wada H, Miyahara R. Expression status of folate receptor alpha is significantly correlated with prognosis in non-small-cell lung cancers. Ann Surg Oncol (2008) 15:889-99. doi:10.1245/s10434-007-9755-3

15. Reddy JA, Haneline LS, Srour EF, Antony AC, Clapp DW, Low PS. Expression and functional characterization of the $\beta$-isoform of the folate receptor on $\mathrm{CD}_{3} 4^{+}$cells. Blood (1999) 93:3940-8.

16. Xia W, Hilgenbrink AR, Matteson EL, Lockwood MB, Cheng JX, Low PS. A functional folate receptor is induced during macrophage activation and can be used to target drugs to activated macrophages. Blood (2009) 113:438-46. doi:10. 1182/blood-2008-04-150789

17. Ross JF, Wang H, Behm FG, Mathew $\mathrm{P}$, Wu M, Booth $\mathrm{R}$, et al. Folate receptor type beta is a neutrophilic lineage marker and is differentially expressed in myeloid leukemia. Cancer (1999) 85:348-57. doi:10.1002/(SICI) 1097-0142(19990115)85:2<348: :AID-CNCR12>3.0.CO;2-4

18. Paulos CM, Turk MJ, Breur GJ, Low PS. Folate receptor-mediated targeting of therapeutic and imaging agents to activated macrophages in rheumatoid arthritis. Adv Drug Deliv Rev (2004) 56:1205-17. doi: 10.1016/j.addr.2004.01.012

19. Lu Y, Stinnette TW, Westrick E, Klein PJ, Gehrke MA, Cross VA, et al. Treatment of experimental adjuvant arthritis with a novel folate receptor-targeted folic acidaminopterin conjugate. Arthritis Res Ther (2011) 13:R56. doi:10.1186/ ar3304

20. Puig-Kröger A, Sierra-Filardi E, Dominguez-Soto A, Samaniego R, Corcuera MT, Gomez-Aguado F, et al. Folate receptor beta is expressed by tumor-associated macrophages and constitutes a marker for M2 anti-inflammatory/regulatory macrophages. Cancer Res (2009) 69:9395-403. doi:10.1158/00085472.CAN-09-2050

21. Kurahara H, Takao S, Kuwahata T, Nagai T, Ding Q, Maeda K, et al. Clinical significance of folate receptor beta-expressing tumorassociated macrophages in pancreatic cancer. Ann Surg Oncol (2012) 19:2264-71. doi:10.1245/ s10434-012-2263-0

22. Low PS, Henne WA, Doorneweerd DD. Discovery and development of folic-acid-based receptor targeting for imaging and therapy of cancer and inflammatory diseases. Acc Chem Res (2008) 41:120-9. doi:10. 1021/ar7000815

23. Kamen BA, Smith AK. A review of folate receptor alpha cycling and 5-methyltetrahydrofolate accumulation with an emphasis on cell models in vitro. Adv Drug Deliv Rev (2004) 56:1085-97. doi:10.1016/j. addr.2004.01.002

24. Zhao R, Diop-Bove N, Visentin M, Goldman ID. Mechanisms of membrane transport of folates into cells and across epithelia. Annu Rev Nutr (2011) 31:177-201. doi:10.1146/ annurev-nutr-072610-145133

25. Leamon CP, Low PS. Folatemediated targeting: from diagnostics to drug and gene delivery. Drug Discov Today (2001) 6:44-51. doi: 10.1016/S1359-6446(00)01594-4

26. Hilgenbrink AR, Low PS. Folate receptor-mediated drug targeting: from therapeutics to diagnostics. J Pharm Sci (2005) 94:2135-46. doi: 10.1002/jps.20457

27. Zhao X, Li H, Lee RJ. Targeted drug delivery via folate receptors. Expert Opin Drug Deliv (2008) 5:309-19. doi:10.1517/17425247.5.3.309

28. Reddy JA, Dorton R, Westrick E, Dawson A, Smith T, Xu LC, et al. Preclinical evaluation of EC145, a folate-vinca alkaloid conjugate. Cancer Res (2007) 67:4434-42. doi: 10.1158/0008-5472.CAN-07-0033

29. Li J, Sausville EA, Klein PJ, Morgenstern D, Leamon CP, Messmann RA, et al. Clinical pharmacokinetics and exposure-toxicity relationship of a folate-vinca alkaloid conjugate EC145 in cancer patients. $J$ Clin Pharmacol (2009) 49:1467-76. doi:10.1177/0091270009339740

30. Dosio F, Milla P, Cattel L. EC-145, a folate-targeted vinca alkaloid conjugate for the potential treatment of folate receptor-expressing cancers. Curr Opin Investig Drugs (2010) 11:1424-33.
31. Edelman MJ, Harb WA, Pal SE, Boccia RV, Kraut MJ, Bonomi P, et al. Multicenter trial of EC145 in advanced, folate-receptor positive adenocarcinoma of the lung. J Thorac Oncol (2012) 7:1618-21. doi:10. 1097/JTO.0b013e318267d051

32. Lorusso PM, Edelman MJ, Bever SL, Forman KM, Pilat M, Quinn MF, et al. Phase I study of folate conjugate EC145 (Vintafolide) in patients with refractory solid tumors. J Clin Oncol (2012) 30:4011-6. doi:10. 1200/JCO.2011.41.4946

33. Pribble P, Edelman MJ. EC145: a novel targeted agent for adenocarcinoma of the lung. Expert Opin Investig Drugs (2012) 21:755-61. doi:10. 1517/13543784.2012.671294

34. Lu YJ, Sega E, Leamon CP, Low PS. Folate receptor-targeted immunotherapy of cancer: mechanism and therapeutic potential. Adv Drug Deliv Rev (2004) 56:1161-76. doi:10.1016/j.addr. 2004.01.009

35. Lu Y, Sega E, Low PS. Folate receptor-targeted immunotherapy: induction of humoral and cellular immunity against hapten-decorated cancer cells. Int J Cancer (2005) 116:710-9. doi:10.1002/ijc.21126

36. Lu Y, Xu LC, Parker N, Westrick E, Reddy JA, Vetzel $M$, et al. Preclinical pharmacokinetics, tissue distribution, and antitumor activity of a folate-hapten conjugate-targeted immunotherapy in hapten-immunized mice. Mol Cancer Ther (2006) 5:3258-67. doi:10.1158/1535-7163.MCT-060439

37. Lu Y, Klein PJ, Westrick E, Xu LC, Santhapuram HK, Bloomfield A, et al. Strategy to prevent drug-related hypersensitivity in folate-targeted hapten immunotherapy of cancer. AAPS J (2009) 11:628-38. doi:10. 1208/s12248-009-9139-7

38. Spannuth WA, Sood AK, Coleman RL. Farletuzumab in epithelial ovarian carcinoma. Expert Opin Biol Ther (2010) 10:431-7. doi:10.1517/ 14712591003592069

39. Clifton GT, Sears AK, Clive KS, Holmes JP, Mittendorf EA, Ioannides $C G$, et al. Folate receptor alpha: a storied past and promising future in immunotherapy. Hum Vaccin (2011) 7:183-90. doi:10. 4161/hv.7.2.13784

40. Coney LR, Tomassetti A, Carayannopoulos L, Frasca V, Kamen BA, Colnaghi MI, et al. Cloning of a tumor-associated antigen: MOv18 and MOv19 antibodies recognize a folate-binding protein. Cancer Res (1991) 51:6125-32. 
41. Coliva A, Zacchetti A, Luison E, Tomassetti A, Bongarzone I, Seregni E, et al. ${ }^{90} \mathrm{Y}$ labeling of monoclonal antibody MOv18 and preclinical validation for radioimmunotherapy of human ovarian carcinomas. Cancer Immunol Immunother (2005) 54:1200-13. doi:10.1007/ s00262-005-0693-2

42. Ebel W, Routhier EL, Foley B, Jacob S, Mcdonough JM, Patel RK, et al. Preclinical evaluation of MORAb003, a humanized monoclonal antibody antagonizing folate receptoralpha. Cancer Immun (2007) 7:6.

43. Smith-Jones PM, Pandit-Taskar N, Cao W, O’Donoghue J, Philips $\mathrm{MD}$, Carrasquillo J, et al. Preclinical radioimmunotargeting of folate receptor alpha using the monoclonal antibody conjugate DOTA-MORAb-003. Nucl Med Biol (2008) 35:343-51. doi:10.1016/j. nucmedbio.2007.12.008

44. Zacchetti A, Coliva A, Luison E, Seregni E, Bombardieri E, Giussani A, et al. ${ }^{177} \mathrm{Lu}-$ labeled MOv18 as compared to ${ }^{131} \mathrm{I}-$ or ${ }^{90}$ Y-labeled MOv18 has the better therapeutic effect in eradication of alpha folate receptorexpressing tumor xenografts. $\mathrm{Nucl}$ Med Biol (2009) 36:759-70. doi:10. 1016/j.nucmedbio.2009.05.004

45. Gabizon A, Shmeeda H, Horowitz AT, Zalipsky S. Tumor cell targeting of liposome-entrapped drugs with phospholipid-anchored folic acidPEG conjugates. Adv Drug Deliv Rev (2004) 56:1177-92. doi:10.1016/j. addr.2004.01.011

46. Pan X, Lee RJ. Tumour-selective drug delivery via folate receptortargeted liposomes. Expert Opin Drug Deliv (2004) 1:7-17. doi:10. 1517/17425247.1.1.7

47. Guo WJ, Lee T, Sudimack J, Lee RJ. Receptor-specific delivery of liposomes via folate-PEG-Chol. J Liposome Res (2000) 10:179-95. doi:10. 3109/08982100009029385

48. Rossin R, Pan D, Qi K, Turner JL, Sun X, Wooley KL, et al. ${ }^{64} \mathrm{Cu}$-labeled folate-conjugated shell cross-linked nanoparticles for tumor imaging and radiotherapy: synthesis, radiolabeling, and biologic evaluation. J Nucl Med (2005) 46:1210-8.

49. Zhang Y, Sun Y, Xu X, Zhu H, Huang L, Zhang X, et al. Radiosynthesis and micro-SPECT imaging of ${ }^{99 \mathrm{~m}} \mathrm{Tc}$-dendrimer poly(amido)amine folic acid conjugate. Bioorg Med Chem Lett (2010) 20:927-31. doi:10.1016/j.bmcl.2009.12.075

50. Tang QS, Chen DZ, Xue WQ, Xiang JY, Gong YC, Zhang L, et al.
Preparation and biodistribution of ${ }^{188}$ Re-labeled folate conjugated human serum albumin magnetic cisplatin nanoparticles ( ${ }^{188}$ Re-folate-CDDP/HSA MNPs) in vivo. Int J Nanomedicine (2011) 6:3077-85. doi:10.2147/IJN.S24322

51. Müller C. Folate based radiopharmaceuticals for imaging and therapy of cancer and inflammation. Curr Pharm Des (2012) 18:1058-83. doi:10.2174/138161212799315777

52. Ke CY, Mathias CJ, Green MA. Folate-receptor-targeted radionuclide imaging agents. Adv Drug Deliv Rev (2004) 56:1143-60. doi: 10.1016/j.addr.2004.01.004

53. Sega EI, Low PS. Tumor detection using folate receptor-targeted imaging agents. Cancer Metastasis Rev (2008) 27:655-64. doi:10.1007/ s10555-008-9155-6

54. Müller C, Schibli R. Folic acid conjugates for nuclear imaging of folate receptor-positive cancer. J Nucl Med (2011) 52:1-4. doi:10.2967/jnumed. 110.076018

55. Müller C, Mindt TL, De Jong M, Schibli R. Evaluation of a novel radiofolate in tumour-bearing mice: promising prospects for folate-based radionuclide therapy. Eur J Nucl Med Mol Imaging (2009) 36:938-46. doi:10.1007/ s00259-008-1058-9

56. Müller C, Vlahov IR, Santhapuram HK, Leamon CP, Schibli R. Tumor targeting using ${ }^{67} \mathrm{Ga}$-DOTABz-folate - investigations of methods to improve the tissue distribution of radiofolates. Nucl Med Biol (2011) 38:715-23. doi:10.1016/ j.nucmedbio.2010.12.013

57. Reber J, Struthers H, Betzel T, Hohn A, Schibli R, Müller C. Radioiodinated folic acid conjugates: evaluation of a valuable concept to improve tumor-to-background contrast. Mol Pharm (2012) 9:1213-21. doi:10.1021/mp200511t

58. Müller C, Forrer F, Schibli R, Krenning EP, De Jong M. SPECT study of folate receptor-positive malignant and normal tissues in mice using a novel ${ }^{99 \mathrm{~m}} \mathrm{Tc}$-radiofolate. $\mathrm{J} \mathrm{Nucl}$ Med (2008) 49:310-7. doi:10.2967/ jnumed.107.045856

59. Valkema R, Pauwels SA, Kvols LK, Kwekkeboom DJ, Jamar F, De Jong $\mathrm{M}$, et al. Long-term follow-up of renal function after peptide receptor radiation therapy with ${ }^{90} \mathrm{Y}$ DOTA $^{0}, \mathrm{Tyr}^{3}$-octreotide and ${ }^{177} \mathrm{Lu}$ DOTA $^{0}, \mathrm{Tyr}^{3}$-octreotate. J Nucl Med (2005) 46(Suppl 1):83S-91S.

60. Bodei L, Cremonesi M, Ferrari M, Pacifici M, Grana CM, Bartolomei $\mathrm{M}$, et al. Long-term evaluation of renal toxicity after peptide receptor radionuclide therapy with ${ }^{90} \mathrm{Y}$ DOTATOC and ${ }^{177}$ Lu-DOTATATE: the role of associated risk factors. Eur J Nucl Med Mol Imaging (2008) 35:1847-56. doi:10.1007/ s00259-008-0778-1

61. Rolleman EJ, Melis M, Valkema R, Boerman OC, Krenning EP, De Jong M. Kidney protection during peptide receptor radionuclide therapy with somatostatin analogues. Eur J Nucl Med $\mathrm{Mo}$ Imaging (2010) 37:1018-31. doi:10. 1007/s00259-009-1282-y

62. Müller C, Brühlmeier M, Schubiger AP, Schibli R. Effects of antifolate drugs on the cellular uptake of radiofolates in vitro and in vivo. $J$ Nucl Med (2006) 47:2057-64.

63. Müller C, Reddy JA, Leamon CP, Schibli R. Effects of the antifolates pemetrexed and CB3717 on the tissue distribution of ${ }^{99 \mathrm{~m}} \mathrm{Tc}$ EC20 in xenografted and syngeneic tumor-bearing mice. $\mathrm{Mol}$ Pharm (2010) 7:597-604. doi:10. $1021 / \mathrm{mp} 900296 \mathrm{k}$

64. Müller C, Struthers H, Winiger C, Zhernosekov K, Schibli R. DOTA conjugate with an albumin-binding entity enables the first folic acid-targeted ${ }^{177} \mathrm{Lu}$ radionuclide tumor therapy in mice. J Nucl Med (2013) 54:124-31. doi:10.2967/jnumed.112.107235

65. Jackman AL, Theti DS, Gibbs DD. Antifolates targeted specifically to the folate receptor. Adv Drug Deliv Rev (2004) 56:1111-25. doi:10. 1016/j.addr.2004.01.003

66. Müller C, Reber J, Schlup C, Leamon CP, Schibli R. In vitro and in vivo evaluation of an innocuous drug cocktail to improve the quality of folic acid targeted nuclear imaging in preclinical research. Mol Pharm (2013) 10:967-74. doi:10. 1021/mp300428p

67. Müller C, Schibli R, Krenning EP, De Jong M. Pemetrexed improves tumor selectivity of ${ }^{111}$ In-DTPAfolate in mice with folate receptorpositive ovarian cancer. $J \mathrm{Nucl}$ Med (2008) 49:623-9. doi:10.2967/ jnumed.107.047704

68. Müller C, Schibli R, Forrer F, Krenning EP, De Jong M. Dosedependent effects of (anti)folate preinjection on ${ }^{99 \mathrm{~m}} \mathrm{Tc}$-radiofolate uptake in tumors and kidneys. $\mathrm{Nucl}$ Med Biol (2007) 34:603-8. doi:10. 1016/j.nucmedbio.2007.06.001

69. Fani M, Tamma ML, Nicolas GP, Lasri E, Medina C, Raynal I, et al. In vivo imaging of folate receptor positive tumor xenografts using novel ${ }^{68} \mathrm{Ga}$-NODAGA-folate conjugates. Mol Pharm (2012) 9:1136-45. doi:10.1021/mp200418f

70. Curtin NJ, Hughes AN. Pemetrexed disodium, a novel antifolate with multiple targets. Lancet Oncol (2001) 2:298-306. doi:10. 1016/S1470-2045(00)00325-9

71. Paz-Ares L, Bezares S, Tabernero JM, Castellanos D, Cortes-Funes H. Review of a promising new agent - pemetrexed disodium. Cancer (2003) 97:2056-63. doi:10.1002/ cncr.11279

72. Bischof M, Weber KJ, Blatter J, Wannenmacher M, Latz D. Interaction of pemetrexed disodium (ALIMTA, multitargeted antifolate) and irradiation in vitro. Int J Radiat Oncol Biol Phys (2002) 52:1381-8. doi:10. 1016/S0360-3016(01)02794-8

73. Huber PE, Bischof M, Jenne J, Heiland S, Peschke P, Saffrich $\mathrm{R}$, et al. Trimodal cancer treatment: beneficial effects of combined antiangiogenesis, radiation, and chemotherapy. Cancer Res (2005) 65:3643-55. doi:10.1158/ 0008-5472.CAN-04- 1668

74. Shewach DS, Lawrence TS. Antimetabolite radiosensitizers. J Clin Oncol (2007) 25:4043-50. doi:10.1200/JCO.2007.11.5287

75. Dennis MS, Zhang M, Meng YG, Kadkhodayan M, Kirchhofer D, Combs D, et al. Albumin binding as a general strategy for improving the pharmacokinetics of proteins. J Biol Chem (2002) 277:35035-43. doi:10.1074/jbc.M205854200

76. Dennis MS, Jin H, Dugger D, Yang R, Mcfarland L, Ogasawara A, et al. Imaging tumors with an albuminbinding Fab, a novel tumortargeting agent. Cancer Res (2007) 67:254-61. doi:10.1158/0008-5472. CAN-06-2531

77. Trüssel S, Dumelin C, Frey K, Villa A, Buller F, Neri D. New strategy for the extension of the serum halflife of antibody fragments. Bioconjug Chem (2009) 20:2286-92. doi: $10.1021 /$ bc9002772

78. Dumelin CE, Trüssel S, Buller F, Trachsel E, Bootz F, Zhang Y, et al. A portable albumin binder from a DNA-encoded chemical library. Angew Chem Int Ed Engl (2008) 47:3196-201. doi:10.1002/ anie. 200704936

79. Reber J, Haller S, Leamon CP, Müller C. ${ }^{177} \mathrm{Lu}-\mathrm{EC} 0800$ combined with the antifolate pemetrexed: preclinical pilot study of folate receptor targeted radionuclide tumor therapy. Mol Cancer Ther (2013). doi:10. 1158/1535-7163.MCT-13-0422-T

80. Bischof M, Huber P, Stoffregen $\mathrm{C}$, Wannenmacher $\mathrm{M}$, Weber 
KJ. Radiosensitization by pemetrexed of human colon carcinoma cells in different cell cycle phases. Int J Radiat Oncol Biol Phys (2003) 57:289-92. doi:10. 1016/S0360-3016(03)00595-9

81. Bischof M, Abdollahi A, Gong P, Stoffregen C, Lipson KE, Debus JU, et al. Triple combination of irradiation, chemotherapy (pemetrexed), and VEGFR inhibition (SU5416) in human endothelial and tumor cells. Int J Radiat Oncol Biol Phys (2004) 60:1220-32. doi:10.1016/j. ijrobp.2004.07.689

82. Müller C, Zhernosekov K, Köster U, Johnston K, Dorrer H, Hohn A, et al. A unique matched quadruplet of terbium radioisotopes for PET and SPECT and for alpha- and beta- radionuclide therapy: an in vivo proof-of-concept study with a new receptor-targeted folate derivative. J Nucl Med (2012) 53:1951-9. doi:10.2967/jnumed. 112.107540

83. Lehenberger S, Barkhausen C, Cohrs S, Fischer E, Grunberg J, Hohn A, et al. The low-energy $\beta^{-}$ and electron emitter ${ }^{161} \mathrm{~Tb}$ as an alternative to ${ }^{177} \mathrm{Lu}$ for targeted radionuclide therapy. $\mathrm{Nucl} \mathrm{Med}$
Biol (2011) 38:917-24. doi:10.1016/ j.nucmedbio.2011.02.007

84. Forrer F, Valkema R, Bernard B, Schramm NU, Hoppin JW, Rolleman E, et al. In vivo radionuclide uptake quantification using a multipinhole SPECT system to predict renal function in small animals. Eur J Nucl Med Mol Imaging (2006) 33:1214-7. doi:10.1007/s00259006-0178-3

85. Sofou S. Radionuclide carriers for targeting of cancer. Int J Nanomedicine (2008) 3:181-99. doi:10.2147/ IJN.S2736

86. Sofou S, Thomas JL, Lin HY, Mcdevitt MR, Scheinberg DA, Sgouros G. Engineered liposomes for potential alpha-particle therapy of metastatic cancer. J Nucl Med (2004) 45:253-60.

87. Henriksen G, Schoultz BW, Michaelsen TE, Bruland OS, Larsen RH. Sterically stabilized liposomes as a carrier for $\alpha$-emitting radium and actinium radionuclides. Nucl Med Biol (2004) 31:441-9. doi:10.1016/j. nucmedbio.2003.11.004

88. Vora A, Riga A, Dollimore D, Alexander KS. Thermal stability of folic acid. Thermochim Acta
(2002) 392:209-20. doi:10.1016/ S0040-6031(02)00103-X

89. Off MK, Steindal AE, Porojnicu AC, Juzeniene A, Vorobey A, Johnsson A, et al. Ultraviolet photodegradation of folic acid. J Photochem Photobiol B (2005) 80:47-55. doi:10.1016/ j.jphotobiol.2005.03.001

90. Dantola ML, Denofrio MP, Zurbano B, Gimenez CS, Ogilby PR, Lorente $\mathrm{C}$, et al. Mechanism of photooxidation of folic acid sensitized by unconjugated pterins. Photochem Photobiol Sci (2010) 9:1604-12. doi:10.1039/ c0pp00210k

91. Hanauske AR, Chen V, Paoletti P, Niyikiza C. Pemetrexed disodium: a novel antifolate clinically active against multiple solid tumors. Oncologist (2001) 6:363-73. doi:10. 1634/theoncologist.6-4-363

92. Gridelli C, Di Maio M. The role of pemetrexed as maintenance treatment in advanced NSCLC: a phase III randomized trial. Expert Opin Pharmacother (2010) 11:321-4. doi: 10.1517/14656560903485672

93. Gridelli C, Maione P, Rossi A, Bareschino MA, Schettino C, Sacco $\mathrm{PC}$, et al. Pemetrexed in advanced non-small cell lung cancer. Expert
Opin Drug Saf(2011) 10:311-7. doi: $10.1517 / 14740338.2011 .553281$

Conflict of Interest Statement: The authors declare that the research was conducted in the absence of any commercial or financial relationships that could be construed as a potential conflict of interest.

Received: 26 April 2013; accepted: 09 September 2013; published online: 24 September 2013.

Citation: Müller C and Schibli R (2013) Prospects in folate receptor-targeted radionuclide therapy. Front. Oncol. 3:249. doi: 10.3389/fonc.2013.00249

This article was submitted to Radiation Oncology, a section of the journal Frontiers in Oncology.

Copyright (c) 2013 Müller and Schibli. This is an open-access article distributed under the terms of the Creative Commons Attribution License (CC BY). The use, distribution or reproduction in other forums is permitted, provided the original author(s) or licensor are credited and that the original publication in this journal is cited, in accordance with accepted academic practice. No use, distribution or reproduction is permitted which does not comply with these terms. 